PRESENTATION TO SIR GEORGE BUCHANAN, F.R.S.

To the Editors of The LANCET.

SIRS,-As you are doubtless aware Sir George Buchanan has lately resigned the post of Medical Officer to the Local Government Board. A committee has been formed with a view to forwarding a movement for enabling those interested in public health throughout the country to give expression to the high estimation in which they hold the important work which Sir George Buchanan has done, and for affording some opportunity for the recognition of his conspicuous services in the cause of preventive medicine. Under these circumstances it has been decided to open a subseription list (not to exceed two guineas from each contributor) with a view to presenting to Sir George Bachanan some pernanent memento of the esteem in which he and his work are held. The Council of the Society of Medical Officers of Health has expressed a desire to be associated with the committee in inviting subscriptions to the fund.

We are, Sirs, faithfully yours,

J. S. BRISTOWE, Hon. Treasurer.

W. H. HAMER,

Ladywell, 69, Dartmouth-park-hill, N.w. Hon.

. C. THRE

The Limes, Chelmsford, Essex.

S Secs.

CommitteE.-Sir Henry Acland Bart., K.C.B., M.D., F R.S., Chairman : Dr. Bristowe, F.R.S., Treasurer; Sir Anthony Home, Bart., K C.B., V.C., M.D. ; Dr. Tatham, Dr. Henry Armstrong; Dr. Whitelegge ; Dr. Maccabe ; Sir William Jenner, Bart. ; Sir George Humphry ; Dr. Thorne Thorne, F.R.S. ; Sir Joseph Fayrer ; Dr. B. W. Richardson ; Dr. Marcet; Shirley F. Murphy, Esq., President; S. R. Lovett, Esq., Hon. Treasurer ;* A. W ynter Blyth, Esq. ;* The Vice-Presidents, Secretaries, and Presidents of Branches,' Professor Lane Not ter Professor J. B. Sanderson; Ernest Clark, Esq., F.S. A.; The Editors of THE LANCET; Dr. Ashby ; Dr. Barwise ; Dr Corfield ; Dr. Davies ; Dr. Bostock Hill ; Dr. Loane ; Dr. Campbell ; Dr. Munro; Dr. Russell ; Dr. Kobinson, Dr Stopford Taylor, Dr. George Wison; Dr. George Matthew Hay. D. Longstaff; Dr. Farquharson, M.P.; Dr. Kuein; Dr. Matthew Hay; Dr. Newsholme; Mr. Harris Butterfeld; Mr M. A. Adams ; Mr. Keith Young ; Mr. Jno Hamer; Mr. Einest Turner ; Dr.
Jas. Niven; Mr. G. H. Fosbroke; Mr. C. E. Paget; Mr. F. Vacher, F.R.C.P Edin., and others.

Representing the Society of Medical Officers of Health.

\section{THE PHYSIOLOGY OF DREAMS.}

\section{To the Editors of THE LANCET.}

SIRS, - I have read with great interest your annotation on the Physiology of Dreams, but unfortunately did not hear the lecture on this subject by Dr. Richarsdon, on which your comments are founded. I am unacquainted with the exact views of the lecturer on the subject, but io is generally held that a dream is simply the working of the brain during sleep, when all surrounding objects are removed from the consciousness, so that it seems for the time a reality, and all the circumstances connected with it so vivid in the memory that they can be realised when the waking hour arrives. The relating of this dream to another person may occupy some time, so numerous are the incidents, and yet the sleep during which it occurred mav be little more than momentary, and herein lies one of the first fallacies with respect to the theory of dreaming. A friend informs me that he has fallen asleep in his carriage, had a dream, and suddenly awoke, when he has found he is not out of the street where his slumber began. For this reason and others which I shall mention it is evident that a dream is nothing more than a mental picture, just as happens when one sits drowsing over the fire in a reverie, and conjurez up to the mind's eye some distant spot where one has once bees, and with ib, perhaps, some well-marked scene, uatil one is living again in the place as if it were a reality. If true sleep should occur, and so all surroundings euts off, the picture becomes still more real, we become a part of it, see the people move about and hear the music play. I believe the dreamer does nothing more than this; he has a picture before him such as we may see in our National Gallery in "The South Sea Bubble" or "The Derby Day." If he had witnessed these scenes himself noly for a minute in a rapid drive through the city or on Eosom Dawne it would take a long time to relate all the particulars of the pictures implanted on his mental vision. So I take it in a dream; there is a mental picture of this kind, but the narrator does not describe it as such, but relates a number of incidents occurring over a lengthened period of time, among

1 To whom contributions may be sent. which are conversations about the names and character of people of whom the dreamer obtains information, there is beautiful music, there is an improvisatore who recites, and various foreign languages are spoken. The narrator of the dream may relate even how he is asked a riddle, and giving it up often obtains the answer from the interrupter : or tell again Boswell's story of Dr. Johnson, how a controversy takes place in which the dreamer has the worst of it. In this case Boswell reminds Johnson that he personified both parbies. This, however, affur ded no explanation of the fact that in acting the part of two people he was $q$ uite unconscious of being the same individual. I take it that it is quite impossible when a person acts the parb of two individuals in a dialogue, that he can for a moment forget his personality. I cannot conceive of the possibility of this, nor can I conceive how, during sleep, the mind could pass through such different stages; but this many persons think they do in a dream.

There is one obvious case which shows the fallacy of the ordinary opinion as to the nature of dreams ; it is one which sorely perplexed one of my studenta. He told me that he had been for a short time to a schoul in Germany, but not long enough to acquire a mastery of the language, whilst of course his master spoke it perfectly. He had often in his dreams returned to his school, when in conversation with his master he spoke only his broken German, whilst his master made use of the best idiom. It greatly puzzled my friend, who, knowing that the dream oriiginated in his own brain, how in his sleep he could be acquainted with the perfect foreign language. I asked him to repeat something which the master had said. This he failed to do, and this is always the case with the relators of dreams; they forget the foreign language spoken, they forget the music they heard, they forget the poem they heard recited, they remember only some triviality or absurd expression which they put into somebody's mouth. Nothing is too extravan gant for a dreamer to say has occurred in his dream, and yet he fully believes that his own brain has concocted it. Although he knows not a note of music, he says, in fact, that his brain has produced the most wonderful melodies although be knows no foreign language, his brain has developed people who spoke them; although he never wrote a verse, his brain during s'eep conceived of $a_{2}$ lady who recited a charming poem. The absurdity of this common opinion is almost too obvious to be mentioned, and yet there are persons who gravely speak of these things occurring during sleep. The fact of their never remembering a word of these performances when awake does not al bogether convince them as it ought, that thev never could have had such dreams as they describe. What is usually said is that the mind during sleep conjures up a variety of scenes and performs, as it were, itself the various parts of the different actors. This is what I deny; the student in his sleep did not talk inferior German, and his master the perfect language. All he did was to picture to himself two people with these different characteristics. He never in his dream talked to his master or his master to him. This is simply the way he describes the picture in his waking hours.

In endeavouring to study the physiology of dreams, and the various causes which give rise to them, the first thing to realise is that the whole vaing is a delusion; to know that the narrator who says he has been dreaming all night long of certain incidents as if it whs a continuous story is deceiving himself; he has merely had a strong mental vision in which the characters have had more reality than in any picture of a scene he can call up in his waking hours. All the living action is a subsequent interpretation. I am not denying the fact of "unconsciotis cerebration," or that the brain may not solve problems during sleep to be made use of when the subject awakes; nor wonld I deny that poets or musicians may have shown their respective powers during sleeping hours. A musician may in his fancy have seen the Devil at the foot of his bed performing a tarantelsa which he wrote down in the morning; or Coleridge might, in a dreamy state at night, compose nis "Kubla Khan," but the poem he wrote during his waking lhours was the offepring of his "vision in a dream." Une difficulty in obtaining a clear idea of the dreaming process appertains to the difficulty which exists, and, perhaps, al ways will exist, in the explana. bion of all mental phenomena, and that is, that in operations of the brain and mind we are obliged, from the necessity of our existence, to put the "ego" anterior to all mental processez. I am, Sirs, yours faithfully, Grosvenor-street, May 7th, 1892. SAMUEL WILKS。 